\title{
Nitrogen Supply Affects Grain Yield by Regulating Antioxidant Enzyme Activity and Photosynthetic Capacity of Maize Plant in the Loess Plateau
}

\author{
Kai Yue ${ }^{1,2}$, Lingling Li 1,2,*iD, Junhong Xie ${ }^{1,2}$, Setor Kwami Fudjoe ${ }^{1,2}$, Renzhi Zhang ${ }^{1,3}$, Zhuzhu Luo ${ }^{1,3}$ \\ and Sumera Anwar ${ }^{4}$ \\ 1 Gansu Provincial Key Laboratory of Aridland Crop Science, Gansu Agricultural University, \\ Lanzhou 730070, China; 13371316862@163.com (K.Y.); xiejh@gsau.edu.cn (J.X.); \\ setkwami1989@gmail.com (S.K.F.); zhangrz@gsau.edu.cn (R.Z.); luozz@gsau.edu.cn (Z.L.) \\ 2 College of Agronomy, Gansu Agricultural University, Lanzhou 730070, China \\ 3 College of Resources and Environment Science, Gansu Agricultural University, Lanzhou 730070, China \\ 4 Institute of Molecular Biology and Biotechnology, The University of Lahore, Lahore 54660, Pakistan; \\ sumeraanwar@mail.hzau.edu.cn \\ * Correspondence: lill@gsau.edu.cn
}

check for

updates

Citation: Yue, K.; Li, L.; Xie, J.; Fudjoe, S.K.; Zhang, R.; Luo, Z.; Anwar, S. Nitrogen Supply Affects Grain Yield by Regulating

Antioxidant Enzyme Activity and Photosynthetic Capacity of Maize Plant in the Loess Plateau. Agronomy 2021, 11, 1094. https://doi.org/ 10.3390/agronomy11061094

Academic Editor: Petronia Carillo

Received: 22 March 2021

Accepted: 25 May 2021

Published: 28 May 2021

Publisher's Note: MDPI stays neutral with regard to jurisdictional claims in published maps and institutional affiliations.

Copyright: (C) 2021 by the authors. Licensee MDPI, Basel, Switzerland. This article is an open access article distributed under the terms and conditions of the Creative Commons Attribution (CC BY) license (https:// creativecommons.org/licenses/by/ $4.0 /)$.

\begin{abstract}
Nitrogen $(\mathrm{N})$ is the most limiting nutrient for maize, and appropriate $\mathrm{N}$ fertilization can promote maize growth and yield. The effect of $\mathrm{N}$ fertilizer rates and timings on morphology, antioxidant enzymes, and grain yield of maize (Zea mays L.) in the Loess Plateau of China was evaluated. The four N levels, i.e., 0 (N0), 100 (N1), 200 (N2), and 300 (N3) kg ha-1, were applied at two timings (T1, one-third $\mathrm{N}$ at sowing and two-thirds at the six-leaf stage of maize; $\mathrm{T} 2$, onethird applied at sowing, six-leaf stage, and eleven-leaf stage of maize). The results show that N2 and N3 significantly increased the plant height, stem and leaf dry weight, and leaf area index of maize compared with a non-N-fertilized control (N0). The net photosynthetic rate, transpiration rate, stomatal conductance, and leaf chlorophyll contents were lower, while the intercellular carbon dioxide concentration was higher for non-fertilized plants compared to fertilized plants. The activities of peroxidase (POD) and superoxide dismutase (SOD) increased with $\mathrm{N}$ rate, but the difference between 200 and $300 \mathrm{~kg} \mathrm{ha}^{-1}$ was not significant; further, the isozyme bands of POD and SOD also changed with their activities. Compared with a non-N-fertilized control, N2 and N3 significantly increased grain yield by 2.76- and 3.11-fold in 2018, 2.74- and 2.80-fold in 2019, and 2.71- and 2.89-fold in 2020, and there was no significant difference between N2 and N3. N application timing only affected yield in 2018. In conclusion, $200 \mathrm{~kg} \mathrm{~N} \mathrm{ha}^{-1}$ application increased yield through optimizing the antioxidant enzyme system, increasing photosynthetic capacity, and promoting dry matter accumulation. Further research is necessary to evaluate the response of more cultivars under more seasons to validate the results obtained.
\end{abstract}

Keywords: nitrogen; maize; morphology; photosynthesis; superoxide dismutase; peroxidase; yield

\section{Introduction}

Nitrogen (N) is typically a limiting nutrient for the production of most of the cereals, and most importantly for maize (Zea mays L.) [1]. The demand for $\mathrm{N}$ fertilizer in cropping systems has substantially increased and $\mathrm{N}$ fertilizer is the most expensive external input in maize production [2]. The Loess Plateau in China is a typical rainfed agricultural region and main area for maize planting, which is approximately equal to $17.9 \%$ of the total area used for crop production $[3,4]$. Nutrient deficiency and insufficient rainfall are the key factors limiting maize yield [5]. To achieve a higher yield, excessive application of $\mathrm{N}$ has been very common in this region [5]. However, excessive $\mathrm{N}$ fertilization does not increase grain yield, also reducing economic efficiency and disrupting the environment [6]. Evidence shows that achieving maximum economic benefits and increasing maize yield is 
possible through the time and rate of $\mathrm{N}$ application in maize [7]. Hence, it is essential to probe the $\mathrm{N}$ application affecting yield in this area, so as to reduce fertilizer inputs without yield reduction.

An optimized $\mathrm{N}$ rate with selection of appropriate $\mathrm{N}$ timing that assures an ample amount of $\mathrm{N}$ is available as obtained by maize to maximize yield [8]. Photosynthesis is a considerable source of dry matter production, which is closely related to yield formation [9]. Variations in photosynthetic parameters are related to $\mathrm{N}$ rate and time, as $\mathrm{N}$ influences the leaf area index (LAI) and chlorophyll [10]. Greater N supply can increase chlorophyll content, thereby increasing the production of photoassimilate, leading to greater rates of growth and higher yield [11]. Additionally, $\mathrm{N}$ is necessary for the synthesis of a myriad of enzymes, structures, and regulatory proteins required for photosynthesis and other metabolic activities [11]. Increasing the $\mathrm{N}$ supply can increase the net photosynthetic rate $(\mathrm{Pn})$ and dry weight of maize to a certain degree [12]. Appropriate time of $\mathrm{N}$ application can improve the accumulation of $\mathrm{N}$ in leaves, and this in turn increases chlorophyll content and photosynthetic capacity, finally enhancing yield [13,14]. The rational use of $\mathrm{N}$ rate and time is an effective way to meet crop $\mathrm{N}$ demands, which ensures the gratifying yield at the agronomic optimum [15]. Although previous research shows that the rate and time of $\mathrm{N}$ application could influence yield via the photosynthetic process, better $\mathrm{N}$ application practices need to be adapted to the environment $[8,9,13,14]$.

The insufficient $\mathrm{N}$ supply causes oxidative stress by excessive production of reactive oxygen species (ROS). Furthermore, ROS can react with key photosynthetic substances, which cause damage to photosystems and contribute to chlorophyll degradation, thus having an adverse effect on yield [16]. Plants have evolved their antioxidant system to repair oxidative damage [17]. In maize leaves, the activities and expression of antioxidant enzymes such as peroxidase (POD), catalase (CAT), and superoxide dismutase (SOD) are closely related to $\mathrm{N}$ supply [18]. The soluble sugar, soluble protein, and activities of POD and SOD have been shown to be significantly increased with $\mathrm{N}$ application up to a certain range [19]. Appropriate $\mathrm{N}$ rate and time could increase antioxidant capacity, which mitigates the toxicity of ROS, eventually leading to photosystem vigor and increased yield [20]. Isozymes catalyze the same chemical reaction, but their protein molecular structure and physicochemical properties are obviously different [21]. Adverse growth conditions can change the composition and activity of the antioxidant enzymes, resulting in changes in the isozyme profile [21,22]. Furthermore, a proper antioxidant system and high rate of photosynthesis during the vegetative stage of maize is vital for grain yield formation [23].

It has been proved that the rate and time of $\mathrm{N}$ application could affect maize yield by controlling photosynthesis and the antioxidant system. However, there is still limited knowledge on how the effects of $\mathrm{N}$ rate and time optimize photosynthesis and antioxidant enzymes in the Loess Plateau. Additionally, $\mathrm{N}$ application is inevitably affected by precipitation, especially in a semi-arid rainfed region. Therefore, based on a field experiment, we explored the optimum rate and time of $\mathrm{N}$ application for maize growth and yield via activities of antioxidant enzymes and photosynthetic characteristics. The aim was to determine the appropriate rate and timing that reduce fertilizer inputs without reducing yield of maize in the Loess Plateau.

\section{Materials and Methods}

\subsection{Site Description}

The study site was located at the Dingxi Experimental Station $\left(35^{\circ} 28^{\prime} \mathrm{N}, 104^{\circ} 44^{\prime} \mathrm{E}\right)$ of Gansu Agricultural University, Gansu Province, in the Loess Plateau of northwest China. The data were collected in 2018, 2019, and 2020. The experimental site has a semiarid climate with an average altitude of $2000 \mathrm{~m}$ above sea level and an annual frost-free period of $140 \mathrm{~d}$. The aeolian soil at the site is Calcaric Cambisol [24] and has a sandy loam texture, slightly alkaline $\mathrm{pH}(8.3), 7.65 \mathrm{~g} \mathrm{~kg}^{-1}$ of soil organic carbon, and $13 \mathrm{mg} \mathrm{kg}^{-1}$ Olsen's phosphorus. The daily maximum air temperature of the site is $38{ }^{\circ} \mathrm{C}$ in July whereas 
the minimum air temperature is $-22{ }^{\circ} \mathrm{C}$ in January. Annual sunshine per year is $2480 \mathrm{~h}$, cumulative air temperature above $10{ }^{\circ} \mathrm{C}$ is $2240{ }^{\circ} \mathrm{C}$, and annual radiation is $5930 \mathrm{MJ} \mathrm{m}^{-2}$. The average annual growing season precipitation at the site during 2018, 2019, and 2020 is shown in Figure 1.

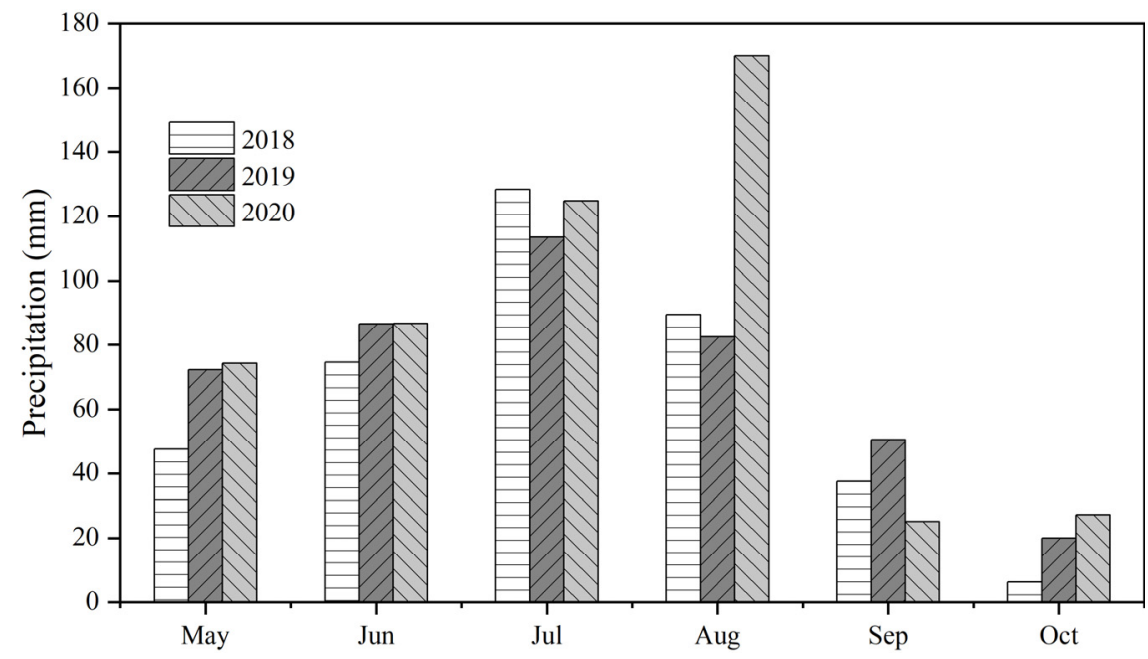

Figure 1. Monthly precipitation during the 2018, 2019, and 2020 study seasons.

\subsection{Experiment Design}

The experiment was laid out in a split-plot design which was based on a randomized complete block design, representing four $\mathrm{N}$ fertilization levels and two $\mathrm{N}$ application timings, with three replications of each treatment. The four $\mathrm{N}$ fertilization levels were N0 (no N fertilizer), N1 (100 kg ha $\left.{ }^{-1}\right), \mathrm{N} 2\left(200 \mathrm{~kg} \mathrm{ha}^{-1}\right)$, and N3 (300 kg ha $\left.{ }^{-1}\right)$. The N was applied using urea $(46 \% \mathrm{~N})$ at sowing, six-leaf collar stage (V6), and eleven-leaf collar stage (V11). The two $\mathrm{N}$ application timings were: (i) $1 / 3 \mathrm{rd}$ of the total $\mathrm{N}$ rate applied at sowing and $2 / 3$ rds at the V6 stage (T1), and (ii) $1 / 3$ rd of the total $\mathrm{N}$ rate applied at sowing, $1 / 3 \mathrm{rd}$ at V6, and 1/3rd at V11 stage of maize (T2). The same treatments were applied to the plots each year.

The phosphorus (P) fertilizer was applied at the rate of $150 \mathrm{~kg} \mathrm{P}_{2} \mathrm{O}_{5} \mathrm{ha}^{-1}$ in the form of triple superphosphate $\left(46 \% \mathrm{P}_{2} \mathrm{O}_{5}\right)$ to all plots. Before sowing, $\mathrm{N}$ and $\mathrm{P}$ fertilizers were hand-applied and incorporated by shallow cultivation, followed by harrowing, whereas $\mathrm{N}$ application at V6 and V11 was performed using a handheld injection device on the side of each maize row. This study utilized complete plastic film mulched in alternate narrow $(0.4 \mathrm{~m})$ and wide $(0.7 \mathrm{~m})$ ridges with furrow planting, which is a new planting technology applied to reduce evaporation [25]. The area of each plot was $18.7 \mathrm{~m}^{2}(4.4 \mathrm{~m} \times 4.25 \mathrm{~m})$ and the width of transparent plastic film was $1.1 \mathrm{~m}$. Maize (cv. Xianyu 335) was planted for a target final stand of 52,500 plants ha ${ }^{-1}$ in late April and harvested in early October of each year.

\subsection{Measurements and Calculations}

\subsubsection{Morphological Characteristics and Dry Weight}

Three maize plants were randomly selected from each plot for measurement of plant height, leaf length, leaf width, and dry weight of stem and leaf tissue at V7 in 2018, V9 in 2019, and V6 in 2020. Dry weight was determined by separating stem and leaf tissues, which were dried in the oven at $80{ }^{\circ} \mathrm{C}$ until constant mass. Leaf area index (LAI) was calculated using the following Equation (1) [26]:

$$
\mathrm{LAI}=0.75 \rho \frac{\sum_{j=1}^{n} \sum_{i=1}^{m}\left(\mathrm{~L}_{i j} \times \mathrm{M}_{i j}\right)}{m}
$$


where 0.75 is the compensation coefficient for maize, $\rho$ is plant density, $\mathrm{L}$ is leaf length, $\mathrm{M}$ is leaf width, $n$ is the total number of leaves per plant, and $m$ is the total number of plants.

\subsubsection{Photosynthetic Indices}

At V9 in 2019 and V6 in 2020, net photosynthetic rate (Pn), transpiration rate (Tr), stomatal conductance (Gs), intercellular carbon dioxide concentration (Ci), and carbon dioxide concentration in the atmosphere (Ca) were recorded with the Portable Gas Exchange Fluorescence System GFS-3000 (Heinz Walz GmbH, Effeltrich, Germany) from 09:00 to 11:00 h under a clear sky. Leaf water use efficiency (WUE) and stomatal limitation (Ls) were calculated according to the following Equations (2) and (3) [27].

$$
\begin{aligned}
& \text { WUE }=\mathrm{Pn} / \mathrm{Tr} \\
& \mathrm{Ls}=1-\mathrm{Ci} / \mathrm{Ca}
\end{aligned}
$$

\subsubsection{Leaf Chlorophyll}

Leaf chlorophyll of maize was assessed using a chlorophyll meter (SPAD-502, KonicaMinolta, Osaka, Japan) at V7, V9, and V6 in 2018, 2019, and 2020, respectively. Readings were taken from the middle of the first fully expanded leaf from 10 plants per plot, and values were averaged.

\subsubsection{Antioxidant Enzyme Activities}

The first fully expanded leaves from the three randomly selected maize plants were collected for enzyme extraction at V9 in 2019 and V6 in 2020. The sampled leaves were stored in liquid $\mathrm{N}$ at $-80^{\circ} \mathrm{C}$. The following steps were carried out at $4{ }^{\circ} \mathrm{C}$ unless stated otherwise. The leaf tissues were homogenized with sodium phosphate buffer $(\mathrm{pH}=7.8)$ and centrifuged at $10,000 \times g$ for $20 \mathrm{~min}$. The supernatant was stored in separate aliquots at $-80^{\circ} \mathrm{C}$, for the SOD and POD analyses. The activity of SOD was measured by nitroblue tetrazolium reduction and POD activity was measured by the guaiacol oxidation process according to $\mathrm{Li}$ [28].

\subsubsection{POD and SOD Isozyme Electrophoresis}

The maize leaf samples were collected at the V9 stage of maize in 2019 for the preparation of the enzyme solution. For this, $0.5 \mathrm{~g}$ of leaves were ground in $5 \mathrm{~mL}$ of pre-cooled phosphate buffer solution $(\mathrm{pH}=7.8)$, containing ethylenediamine tetraacetic acid $(0.21 \mathrm{mg})$ and polyvinylpyrrolidone (50 mg). The mixture was centrifuged at $4{ }^{\circ} \mathrm{C}$ and high speed $\left(15,000 \mathrm{r} \cdot \mathrm{min}^{-1}\right)$ for $15 \mathrm{~min}$ and the supernatant (enzyme solution) was stored at $-20^{\circ} \mathrm{C}$ for later use.

The enzyme solution was mixed with the sample treatment solution ( $5 \mathrm{~g}$ of sucrose, $0.5 \mathrm{~mL}$ of $0.1 \%$ bromophenol blue, and $14.5 \mathrm{~mL}$ of distilled water) at a $1: 1$ ratio and shaken well. For the vertical discontinuous polyacrylamide gel electrophoresis, riboflavin was used as the polymerization initiator and the gel was polymerized under light conditions for $30 \mathrm{~min}$. The mass fraction of POD isozyme was 7.5\%, SOD isozyme mass fraction was $10 \%$, and the mass fraction of spacer gel was $3.75 \%$. The loading amount of POD and SOD was $20 \mu \mathrm{L}$ and electrophoresis was conducted at $4{ }^{\circ} \mathrm{C}$. The voltage of the concentrated glue was $80 \mathrm{~V}$ and the current was $30 \mathrm{~mA}$, and the voltage of the separating glue was $200 \mathrm{~V}$ and the current was $45 \mathrm{~mA}$. When the bromophenol blue indicator moved to the front edge, electrophoresis was stopped.

The modified benzidine method was used for POD isozyme staining [29]. For SOD isozyme staining, nitroblue tetrazolium was used [29]. The gel was illuminated under a fluorescent lamp for 10 to $15 \mathrm{~min}$ until the transparent spectral band appeared.

\subsubsection{Grain Yield}

All ears of corn in each plot were air-dried and the yield was calculated at $14 \%$ moisture. 


\subsection{Statistical Analysis}

Data were analyzed using ANOVA with SPSS 19.0 (IBM Corporation, Armonk, NY, USA). Differences were compared using the least significant difference test (LSD) at the 0.05 level of probability. Pearson's correlations coefficients were used to analyze the relationships between grain yield and physiological traits. Figures in the article were plotted using Origin 2019 (OriginLab Corporation, Northampton, MA, USA).

\section{Results}

\subsection{Maize Morphological Characteristics as Affected by N Supply}

N2 and N3 increased plant height compared with N0. T1 and T2 did not differ significantly at the same N rate except at N2 in 2018 (T2 > T1) and N1 in 2020 (T1 > T2) (Figure 2a-c). In 2018, the plant height under N2 and N3 treatments increased by 51.67 and $52.79 \%$ compared with N0 at V7. However, T2 significantly reduced by $11.32 \%$ in plant height under N2 compared with T1. In 2019, the plant height at V9 was significantly higher under the N2 and N3 than under no fertilizer, and was increased by 93.06 and $95.15 \%$. In 2020, the plant height of N2 and N3 increased by 24.31 and 31.29\% compared with N0. Leaf area index (LAI) of maize under N0 was significantly lower as compared to N2 and N3 (Figure 2d-f). There was no significant difference in LAI under N2 and N3, and it increased by 98.25 and $102.04 \%$ in 2018, 164.43 and $164.49 \%$ in 2019 , and 48.61 and $44.47 \%$ in 2020 compared to N0, respectively.
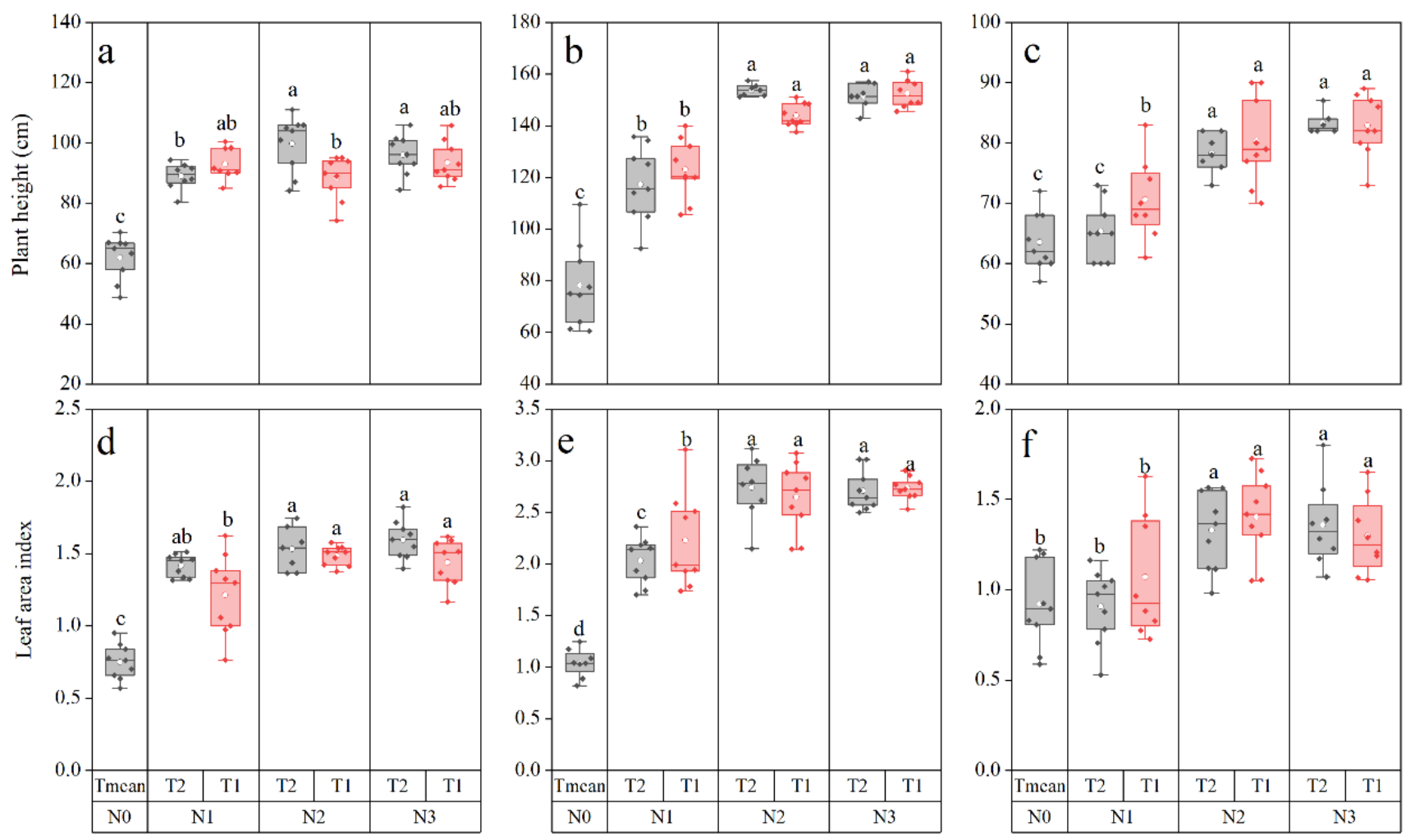

Figure 2. Plant height and leaf area index of maize in 2018 (a,d), 2019 (b,e), and 2020 (c,f) in response to the rate and timing of nitrogen (N). Differences were compared using the least significant difference test (LSD) at the 0.05 level of probability. Different letters indicate significant differences at $p<0.05$. N0: no N fertilizer, N1: $100 \mathrm{~kg} \cdot \mathrm{N} \cdot \mathrm{ha}{ }^{-1}, \mathrm{~N} 2: 200 \mathrm{~kg} \cdot \mathrm{N} \cdot \mathrm{ha}{ }^{-1}$, N3: $300 \mathrm{~kg} \cdot \mathrm{N} \cdot \mathrm{ha}^{-1}, \mathrm{~T} 1$ : one-third of the total $\mathrm{N}$ rate applied at sowing and the remaining two-thirds at V6, T2: one-third of the total $\mathrm{N}$ rate applied at sowing, V6 stage, and V11 stage of maize.

Stem and leaf dry weight were significantly higher with $\mathrm{N}$ supply than N0, and reached a maximum under N2T2 in 2018, N3T1 in 2019, and N2T1 in 2020 (Figure 3). In 2018, stem dry weight and leaf dry weights were 72 and 59\% less in N0 than in N2T2, 
respectively, while in 2019 stem dry weight and leaf dry weight were 80 and 76\% less under N0, respectively, as compared to N3T1. In 2020, there was no significant difference between $\mathrm{N} 0$ and N1 in stem and leaf dry weight. On average, N2 and N3, respectively, increased stem and leaf dry weight by 129.96 and $64.99 \%$ and 104.05 and $53.72 \%$ compared with N0 in 2020.
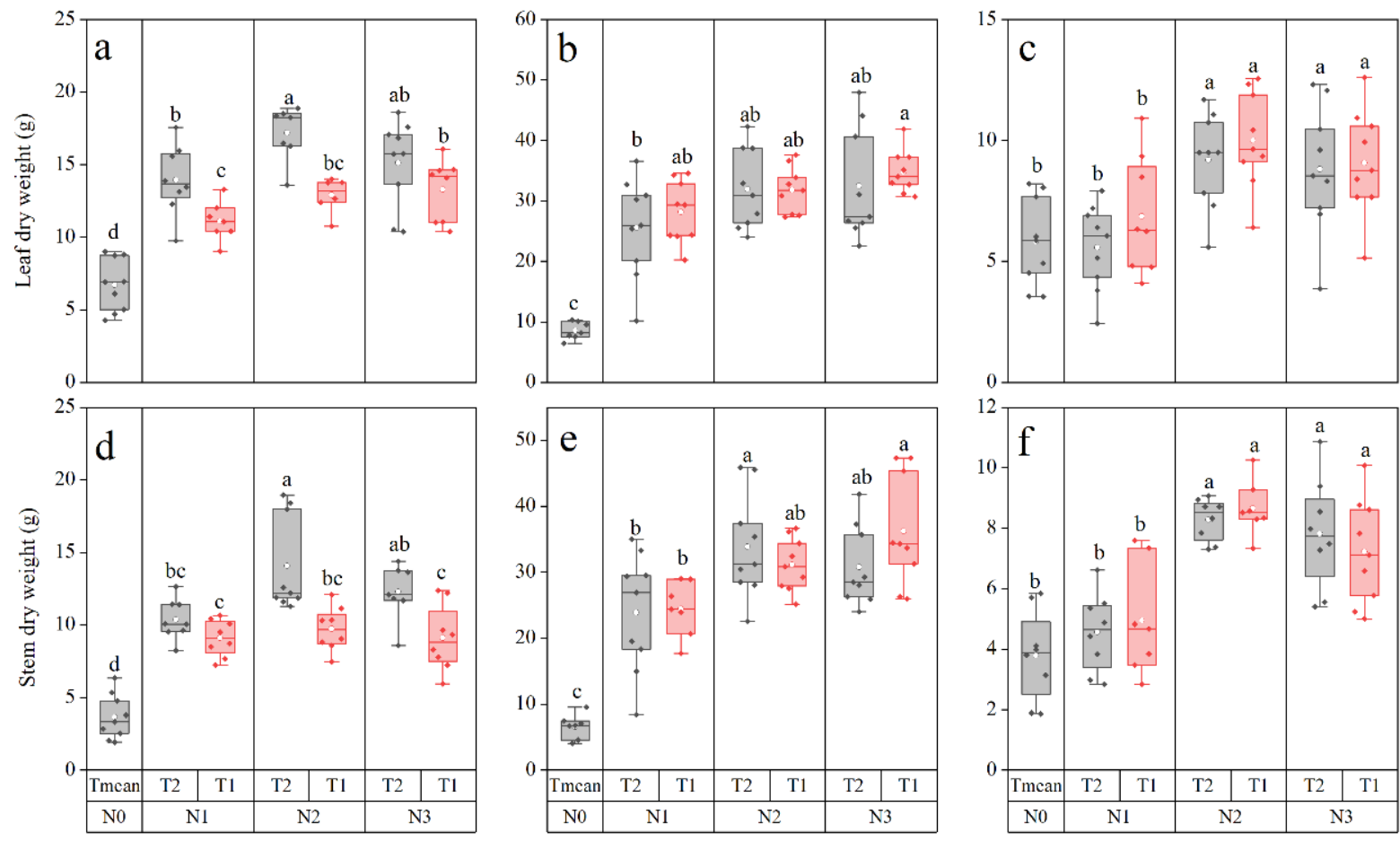

Figure 3. Stem dry weight and leaf dry weight of maize in $2018(\mathbf{a}, \mathbf{d}), 2019(\mathbf{b}, \mathbf{e})$, and $2020(\mathbf{c}, \mathbf{f})$ in response to the rate and timing of N. Different letters indicate significant differences at $p<0.05$.

\subsection{Leaf Chlorophyll as Affected by N Supply}

Leaf chlorophyll contents of maize, as indicated by the leaf chlorophyll meter (SPAD) value, increased with the N supply (Figure 4). The chlorophyll at N1, N2, and N3 was higher than N0, although there was no significant difference between the N2 and N3 treatment levels. Under the same level of $\mathrm{N}$ application, there was no significant difference between the T1 and T2 treatments. The leaf SPAD value of N2 and N3 was 44.82 and 56.38, 88.82 and 91.60 , and 51.25 and $46.70 \%$ higher as compared to that with N0 in 2018, 2019, and 2020, respectively.
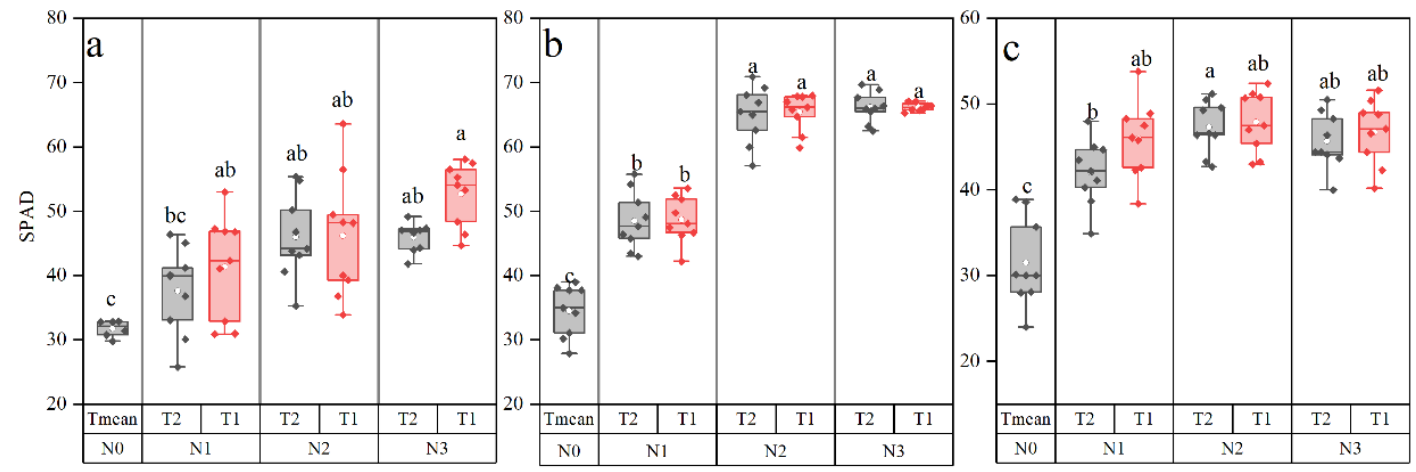

Figure 4. Leaf chlorophyll of maize in 2018 (a), 2019 (b), and 2020 (c) as affected by N supply. Different letters indicate significant differences at $p<0.05$. 


\subsection{Leaf Photosynthetic Characteristics as Affected by N Supply}

Nitrogen rate, rather than $\mathrm{N}$ time and the combination of $\mathrm{N}$ rate and time, significantly affected photosynthetic characteristics, but there was no significant difference between T1 and $\mathrm{T} 2$ under the same $\mathrm{N}$ level (except for transpiration rate and stomatal conductance under N1 in 2020) (Table 1). The net photosynthesis (Pn), transpiration rate (Tr), stomatal conductance (Gs), and stomatal limitation (Ls) of maize leaves increased with increasing the amount of $\mathrm{N}$ fertilizer. There was no significant difference between N2 and N3 in photosynthetic characteristics, and N2 increased Pn and leaf water use efficiency (WUE) by 2.42- and 1.51-fold in 2019, and 4.06- and 1.27-fold in 2020 compared with N0. Intercellular carbon dioxide concentration ( $\mathrm{Ci}$ ) was decreased with $\mathrm{N}$ application and the lowest was observed at N0.

Table 1. Photosynthetic characteristics of maize as affected by nitrogen (N) supply treatment.

\begin{tabular}{|c|c|c|c|c|c|c|c|c|}
\hline Year & N Rate & N Timing & $\frac{P_{n}}{\left(\mu \mathrm{mol} \cdot \mathrm{m}^{-2} \cdot \mathrm{s}^{-1}\right)}$ & $\frac{\mathrm{G}_{\mathrm{s}}}{\left(\mu \mathrm{mol} \cdot \mathrm{m}^{-2} \cdot \mathrm{s}^{-1}\right)}$ & $C_{i}(p p m)$ & $\begin{array}{c}\operatorname{Tr} \\
\left(\mathrm{mmol} \cdot \mathrm{m}^{-2} \cdot \mathrm{s}^{-1}\right)\end{array}$ & $L_{s}(\%)$ & $\begin{array}{c}\text { WUE } \\
\left(\mu \mathrm{mol} \cdot \mathrm{CO}_{2} \cdot\right. \\
\left.\mathrm{mmol}^{-1} \cdot \mathrm{H}_{2} \mathrm{O}\right)\end{array}$ \\
\hline \multirow{10}{*}{2019} & No & & $18.53^{b}$ & $215.24^{b}$ & $206.24^{a}$ & $7.07^{b}$ & $0.42^{c}$ & $2.62^{\mathrm{d}}$ \\
\hline & N1 & $\mathrm{T} 2$ & $24.59^{b}$ & $246.26^{b}$ & $185.35^{a b}$ & $6.81^{b}$ & $0.47^{b c}$ & $3.61^{b c}$ \\
\hline & N1 & $\mathrm{T} 1$ & $26.04^{\mathrm{ab}}$ & $232.25^{b}$ & $161.52^{b}$ & $7.36^{b}$ & $0.54^{b}$ & $3.54^{c}$ \\
\hline & N2 & $\mathrm{T} 2$ & $42.70^{\mathrm{a}}$ & $312.80^{a}$ & $103.06^{\mathrm{a}}$ & $10.75^{a}$ & $0.69^{a}$ & $3.97^{a b c}$ \\
\hline & N2 & $\mathrm{T} 1$ & $46.84^{\mathrm{a}}$ & $360.26^{a}$ & $105.16^{a}$ & $11.89^{\mathrm{a}}$ & $0.67^{\mathrm{a}}$ & $3.95^{a b c}$ \\
\hline & N3 & $\mathrm{T} 2$ & $43.65^{a}$ & $323.19^{a}$ & $97.12^{\mathrm{a}}$ & $10.80^{\mathrm{a}}$ & $0.70^{\mathrm{a}}$ & $4.06^{\mathrm{ab}}$ \\
\hline & N3 & $\mathrm{T} 1$ & $47.53^{\mathrm{a}}$ & $374.23^{a}$ & $109.40^{\mathrm{a}}$ & $11.48^{\mathrm{a}}$ & $0.66^{\mathrm{a}}$ & $4.14^{\mathrm{a}}$ \\
\hline & & $\mathrm{N}$ & $79.08^{* *}$ & $21.87^{* *}$ & $63.31^{* *}$ & $51.07 * *$ & $46.11 * *$ & $35.24^{* *}$ \\
\hline & F-value & $\mathrm{T}$ & $2.35^{\mathrm{ns}}$ & $2.14^{\mathrm{ns}}$ & $0.13^{\mathrm{ns}}$ & $3.11^{\mathrm{ns}}$ & $0.01^{\mathrm{ns}}$ & $0.00^{\mathrm{ns}}$ \\
\hline & & $\mathrm{N} \times \mathrm{T}$ & $0.42^{\mathrm{ns}}$ & $1.31^{\mathrm{ns}}$ & $1.39^{\mathrm{ns}}$ & $0.48^{\mathrm{ns}}$ & $1.38^{\mathrm{ns}}$ & $0.09^{\mathrm{ns}}$ \\
\hline \multirow{10}{*}{2020} & N0 & & $9.02^{d}$ & $126.93^{c}$ & $226.74^{\mathrm{a}}$ & $3.19^{\mathrm{d}}$ & $0.36^{b}$ & $2.98^{a b}$ \\
\hline & N1 & $\mathrm{T} 2$ & $23.43^{c}$ & $227.14^{b}$ & $191.03^{a b}$ & $7.28^{c}$ & $0.44^{\mathrm{ab}}$ & $3.21^{\mathrm{ab}}$ \\
\hline & N1 & $\mathrm{T} 1$ & $24.91^{\mathrm{C}}$ & $310.08^{a}$ & $203.18^{a b}$ & $8.74^{\mathrm{b}}$ & $0.40^{\mathrm{ab}}$ & $2.85^{\mathrm{b}}$ \\
\hline & N2 & $\mathrm{T} 2$ & $34.76^{\mathrm{ab}}$ & $332.62^{a}$ & $145.76^{b c}$ & $9.49^{a b}$ & $0.55^{\mathrm{ab}}$ & $3.67^{a b}$ \\
\hline & N2 & $\mathrm{T} 1$ & $38.56^{\mathrm{ab}}$ & $318.63^{a}$ & $122.03^{c}$ & $9.92^{\mathrm{a}}$ & $0.62^{a b}$ & $3.87^{a b}$ \\
\hline & N3 & $\mathrm{T} 2$ & $43.02^{\mathrm{a}}$ & $334.32^{\mathrm{a}}$ & $104.81^{\mathrm{c}}$ & $10.46^{\mathrm{a}}$ & $0.67^{\mathrm{a}}$ & $4.12^{\mathrm{a}}$ \\
\hline & N3 & $\mathrm{T} 1$ & $38.94^{\mathrm{ab}}$ & $327.31^{\mathrm{a}}$ & $122.65^{c}$ & $9.80^{\mathrm{ab}}$ & $0.62^{\mathrm{ab}}$ & $3.97^{a b}$ \\
\hline & & $\mathrm{N}$ & $82.90 * *$ & $43.18^{* *}$ & $13.36^{* *}$ & $146.26^{* *}$ & 3.90 * & 3.54 * \\
\hline & F-value & $\mathrm{T}$ & $0.04^{\mathrm{ns}}$ & $1.15^{\mathrm{ns}}$ & $0.01^{\mathrm{ns}}$ & $1.34^{\mathrm{ns}}$ & $0.62^{\mathrm{ns}}$ & $0.08^{\mathrm{ns}}$ \\
\hline & & $\mathrm{N} \times \mathrm{T}$ & $1.11^{\mathrm{ns}}$ & $2.46^{\mathrm{ns}}$ & $0.41^{\mathrm{ns}}$ & $2.84^{\mathrm{ns}}$ & $0.91^{\mathrm{ns}}$ & $0.17^{\mathrm{ns}}$ \\
\hline
\end{tabular}

N0: no N fertilizer; N1, N2, and N3 indicate 100, 200, and $300 \mathrm{~kg} \mathrm{~N} \mathrm{ha}^{-1}$, respectively; T1: one-third of the total $\mathrm{N}$ rate applied at sowing and two-thirds applied at V6; T2: one-third of the total $\mathrm{N}$ rate applied at sowing, V6, and V11; $P_{n}$, net photosynthetic rate; Tr, transpiration rate; $G_{s}$, stomatal conductance; $C_{i}$, intercellular carbon dioxide concentration; $L_{s}$, stomatal limitation; WUE, leaf water use efficiency. Differences were compared using the least significant difference test (LSD) at the 0.05 level of probability. Different letters indicate a significant difference in means within a column at $p<0.05$. ns, not significant at $p<0.05 ;{ }^{*}$, significant at $p<0.05 ;{ }^{* *}$, significant at $p<0.01$.

\subsection{Antioxidant Enzyme Activities as Affected by N Supply}

Peroxidase (POD) and superoxide dismutase (SOD) activity in maize leaves gradually increased with the $\mathrm{N}$ rate, and $\mathrm{N}$ application time had no significant effect on POD and SOD activity (Figure 5). Peroxidase activity was greater with N2 and N3, under which POD was almost 2-fold higher in 2019 and 1.2-fold higher than N0. The activity of SOD with N2 and N3 was significantly higher than that with N1 in 2019, while SOD activity with N2 and N3 showed no significant difference from that with N1 in 2020. On average, the superoxide dismutase (SOD) activity of N2 and N3 was increased by 76.36 and $83.59 \%$ in 2019 , and 72.10 and $75.57 \%$ in 2020 from that with N0.

\subsection{POD and SOD Isozyme Activities as Affected by N Supply}

The POD isozyme bands were significantly different among $\mathrm{N}$ rates and their activity was also different in expression (Figure 6a). A total of five POD isozyme bands were detected in this study. For N0 (fifth lane), the P3 and P4 bands were lighter than the other bands. At the same N level, N2T2 (lane 2) was darker than N2T1 (lane 6), and the isozyme activity was enhanced. 

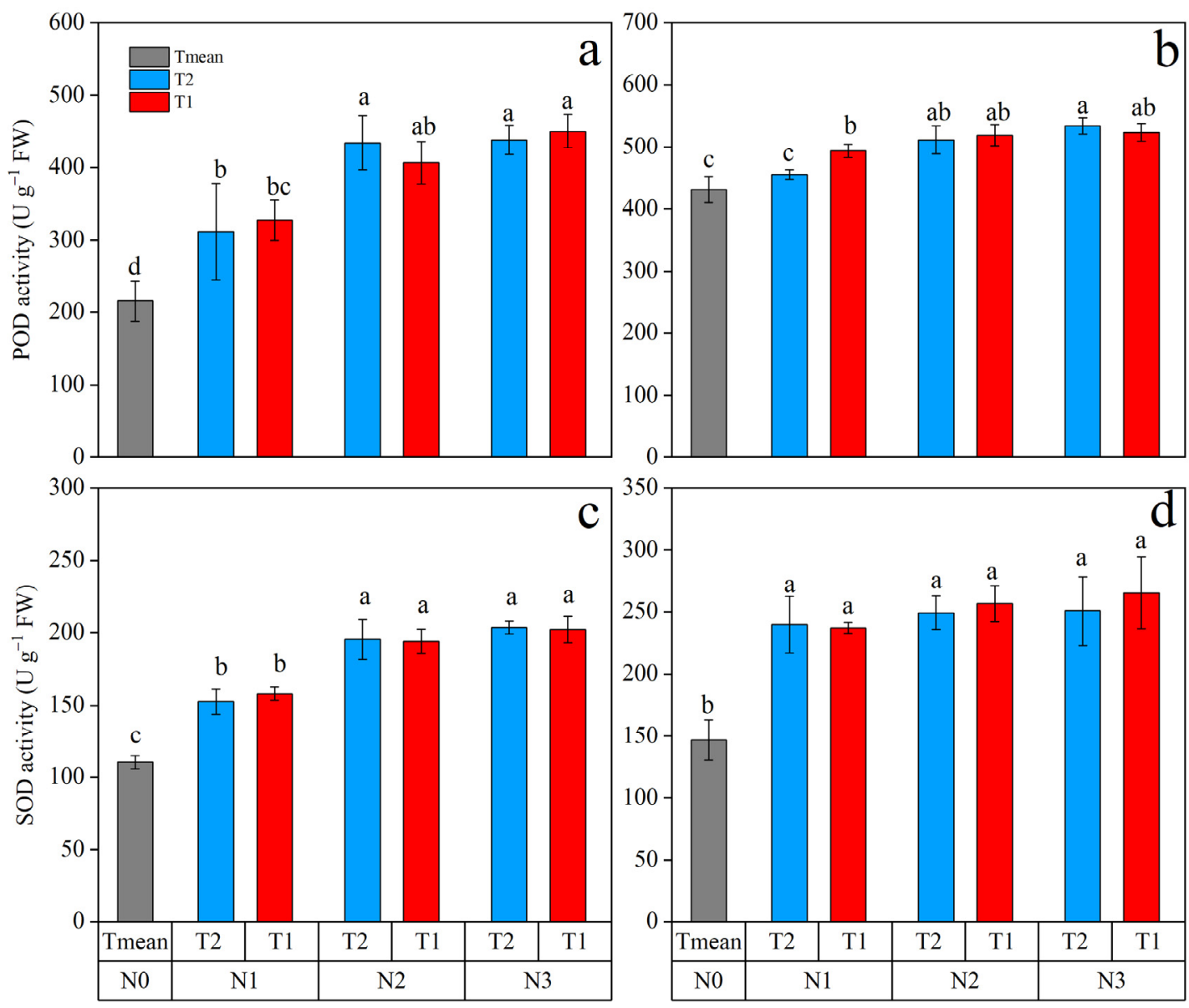

Figure 5. Activity of peroxidase (POD) and superoxide dismutase (SOD) enzymes in leaves of maize affected by $\mathrm{N}$ supply in $2019(\mathbf{a}, \mathbf{c})$ and $2020(\mathbf{b}, \mathbf{d})$. Different letters indicate significant differences at $p<0.05$.
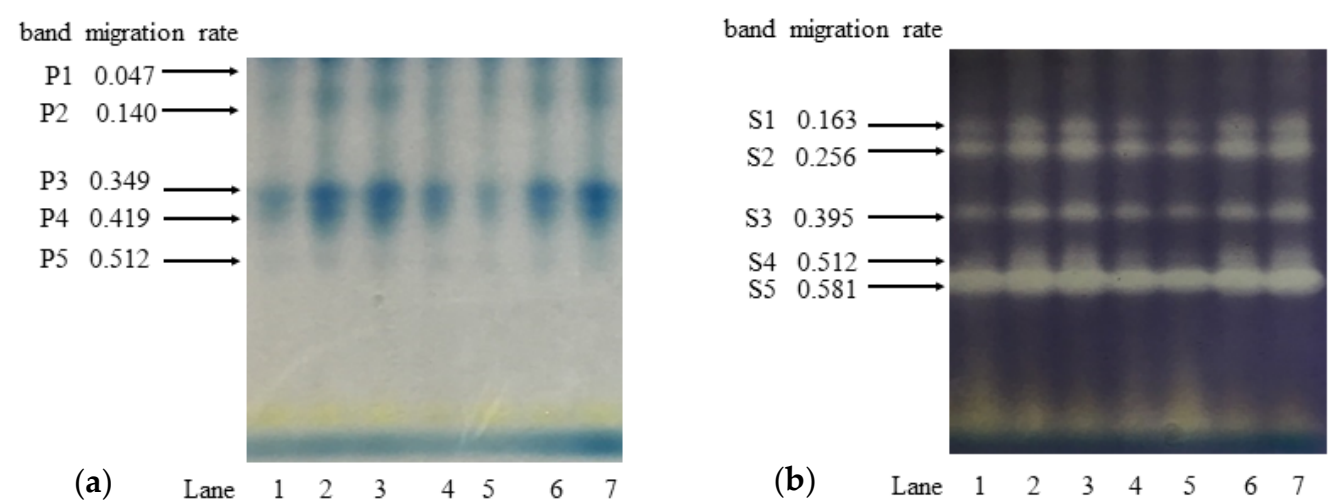

Figure 6. Activity of (a) peroxidase (POD) and (b) superoxide dismutase (SOD) isozyme in leaves of maize as affected by N supply treatments in 2019. lane 1: N1T2, lane 2: N2T2, lane 3: N3T2, lane 4: N1T1, lane 5: N0, lane 6: N2T1, and lane 7: N3T1. P1-5: different bands of the POD isozyme, and S1-5: different bands of the SOD isozyme.

Nitrogen fertilization influenced the expression level of SOD isozyme bands (S1, S2, S3, and S4) (Figure 6b). The intensity of bands in low N levels, N1T2 (lane 1), N1T1 (lane 4), and N0 (lane 5), was significantly lighter than the high N levels, N2T2 (lane 2), N3T2 (lane 3), N2T1 (lane 6), and N3T1 (lane 7). At a given $\mathrm{N}$ level, $\mathrm{N}$ application timing did not significantly affect the intensity of the enzyme band. 


\subsection{Grain Yield as Affected by N Supply}

Analysis of variance showed that $\mathrm{N}$ application significantly affected the grain yield of maize; however, no significant difference was found between $\mathrm{T} 1$ and $\mathrm{T} 2$ for a given $\mathrm{N}$ rate in grain yield (Figure 7). Compared with N0, the application of N3 and N2 significantly increased grain yield by 3.11- and 2.76-fold in 2018, 2.80- and 2.74-fold in 2019, and 2.71and 2.89-fold in 2020. The grain yields at N2T1, N3T1, and N3T2 showed no significant difference and were statistically similar in both years. However, N3T2 significantly increased grain yield by 1.26-fold compared with N2T2 in 2018.
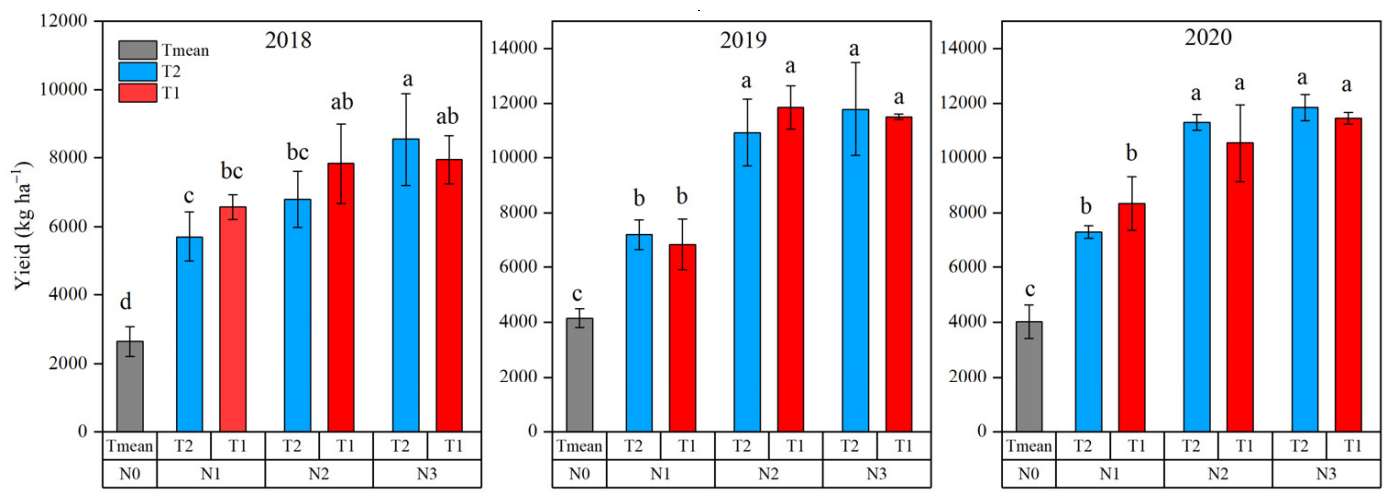

Figure 7. Grain yield of maize in 2018, 2019, and 2020, as affected by N supply. Different letters indicate significant differences at $p<0.05$.

\subsection{Correlation Analysis of Antioxidant Enzyme Activities, Photosynthetic and Morphological Characteristics, and Yield}

We examined the correlation analysis of antioxidant enzyme activities, photosynthetic and morphological characteristics, and yield in 2019 and 2020. Across the different $\mathrm{N}$ supply rates and times, the LAI, leaf chlorophyll, and antioxidant enzyme activities were positively correlated with $P_{n}$ of the maize leaves (Figure 8). There was a significant positive correlation between $P_{n}$ and stem dry weight and leaf dry weight. In addition, stem dry weight and leaf dry weight were positively correlated with yield. Oppositely, there was a negative correlation between $C i$ and yield.
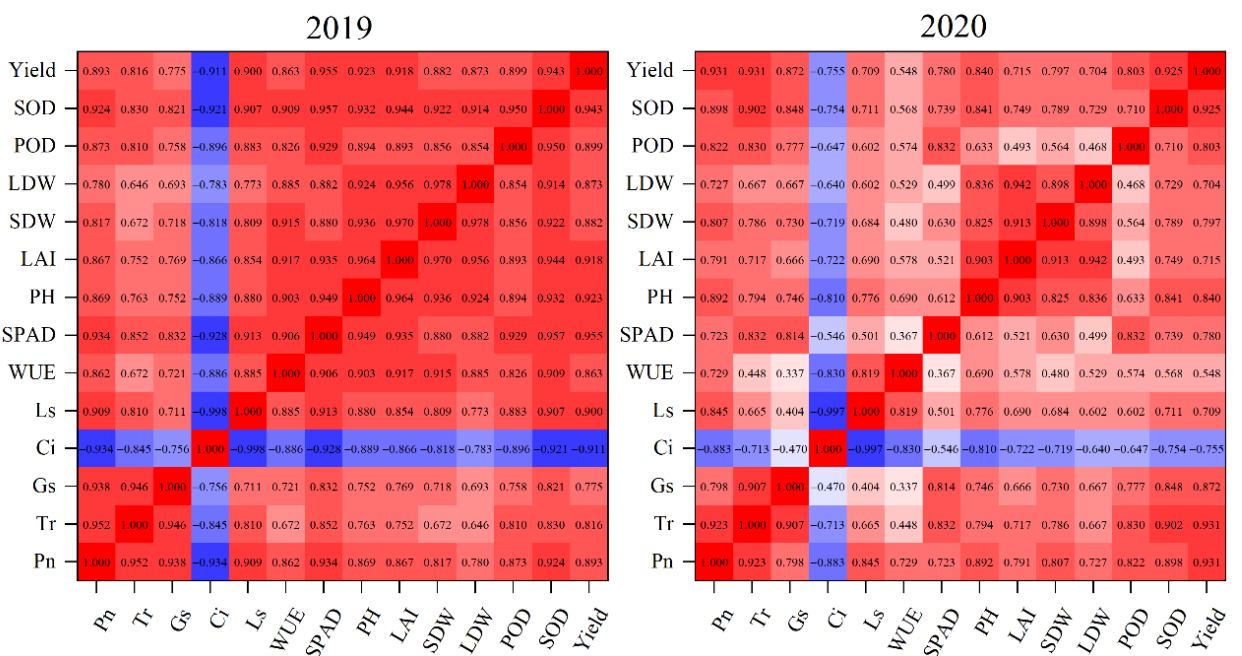

Figure 8. Correlation analysis of antioxidant enzyme activities, photosynthetic and morphological characteristics, and yield. Pn, net photosynthetic rate; Tr, transpiration rate; Gs, stomatal conductance; $\mathrm{Ci}$, intercellular carbon dioxide concentration; Ls, stomatal limitation; WUE, leaf water use efficiency; chl, chlorophyll as indicated by the SPAD value; PH, plant height; SDW stem dry weight; LDW, leaf dry weight; LAI, leaf area index; POD, activities of peroxidase; SOD, superoxide dismutase. 


\section{Discussion}

The jointing stage of maize, a period from V6 to V9, is important as it establishes the foundation for maize growth and yield formation [30]. Appropriate $\mathrm{N}$ supply and management can significantly improve maize dry matter and lead to robust plants [31]. In this study, maize plant height was significantly lower with N0 compared to the N2 and $\mathrm{N} 3$ treatments; however, N3 treatment did not significantly increase plant morphological characteristics compared to the $\mathrm{N} 2$ treatment. These data indicate that insufficient $\mathrm{N}$ supply restricts the growth of plants due to reduced carbohydrate metabolism; however, given the lack of significant difference between N2 and N3, N2 is sufficient for maize growth and development [32]. The role of $\mathrm{N}$ was remarkable in enhancing LAI, which might be owing to its role in improving leaf expansion [33]. Leaf expansion increased the storage capacity of $\mathrm{N}$ in leaves and promoted carbon supply to the stalk, resulting in high maize production [34]. Our research showed that the variation in dry matter under different $\mathrm{N}$ rates was a result of differences in plant height, which had significant linear relationships with dry matter [35]. On the other hand, N2 and N3 increased LAI and chlorophyll contents, which led to greater accumulation of photosynthate, and eventually, promoting an increase in dry matter [33]. Net photosynthesis is a key factor in determining maize grain yield, and the maintenance of a favorable Pn could increase maize production [36]. In the present study, $\mathrm{N}$ application affected photosynthetic characteristics, especially the Pn, which was similar to previous reports [37]. The $\mathrm{N}$ supply can affect the $\mathrm{N}$ content in leaves, which is mainly located in the photosynthetic protein complex, thereby affecting photosynthesis [38]. Our research found Pn showed an increasing trend with increased N application, which eventually led to an increase in production. However, Pn would not continue to increase beyond a certain amount of N. Some researchers also have found a threshold for increasing the amount of $\mathrm{N}$ to increase photosynthesis, and that photosynthesis decreases when the threshold is exceeded [39]. The variation in Pn under different $\mathrm{N}$ applications could be considered as due to stomatal and/or non-stomatal limitations, which could be determined by Pn, Ls, and Ci [40]. Our results show that N0 limited Pn and Ls while increasing Ci. These results provide further evidence that the Pn caused by $\mathrm{N}$ deficiency was mainly caused by non-stomatal limitation, such as the membrane structural integrity of the photosynthetic apparatus and the associated enzyme activities [41]. Chlorophyll is a key biochemical component in photosynthesis, which participates in light energy absorption, transport, and conversion [36]. There is a strong relationship between chlorophyll content and the photosynthetic capacity of leaves, and $\mathrm{N}$ supply can increase the chlorophyll content of maize [42]. Moderate $\mathrm{N}$ application has been shown to increase leaf chlorophyll content, which promotes the Pn, and thus leads to an increase in yield [42]. In the present study, compared with no $\mathrm{N}$ application, all treatments with $\mathrm{N}$ application significantly increased chlorophyll content, similar to previous reports [37]. Wang et al. found that $\mathrm{N}$ applied at sowing, V6, and V11 of maize can result in higher levels of leaf chlorophyll in maize compared to all $\mathrm{N}$ applied at sowing [43].

Chlorophyll degradation is closely related to reactive oxygen species (ROS). Low concentrations of $\mathrm{N}$ in plant cells causes senescence and production of ROS, which in extreme conditions leads to cell death [44]. $\mathrm{N}$ deficiency directly affects the production of antioxidant enzymes, and a plant's ability to scavenge ROS is slower than the production, which leads to oxidative stress by ROS [45]. In this study, the activity of antioxidant enzymes was increased as the $\mathrm{N}$ application rate increased from 0 to $200 \mathrm{~kg} \mathrm{~N} \cdot \mathrm{ha}^{-1}$; however, the difference in antioxidant enzymes between N2 and N3 was not significant. That is, N2 and N3 treatment showed the highest antioxidant enzyme activities to scavenge ROS. In contrast, the increase in antioxidant enzyme activities did not relieve the toxicity of ROS, which caused damage to photosystems and resulted in chlorophyll degradation. Wang et al. (2013) indicated that the appropriate rate of $\mathrm{N}$ application can improve the activity of protective enzymes, enhance the scavenging ability of mesophyll cells against ROS, and maintain the stability of cells, ultimately increasing yield [46]. Deficiency in nutrients can lead to changes in antioxidant isozymes [47]. The results of this study show 
that the expression of the POD and SOD isozymes in maize leaves at V9 changed under different $\mathrm{N}$ applications, but the number of bands did not change. The expression levels of $\mathrm{N} 2$ and $\mathrm{N} 3$ were higher than that of $\mathrm{N} 0$ and $\mathrm{N} 1$. This indicates that free radicals were easier to get rid of under the condition of N2 and N3, which contributed to plant growth [48].

Grain yield is the main target of crop production. We found that yield was affected positively by dry matter, LAI, antioxidant enzymes, and $\mathrm{Pn}$, and negatively by $\mathrm{Ci}$, from correlation analysis. Grain yield was significantly affected by $\mathrm{N}$ application rate, but no significant differences were observed between N2T1 and N3. As reported by Chen et al. (2015), N application significantly increased yield frocm 0 to $240 \mathrm{~kg} \mathrm{ha}^{-1}$, and two maize hybrids (XY335 and ZD958) did not show a significant difference in yield, but XY335 increased the amount of vegetative $\mathrm{N}$ remobilization [49]. Joshi et al. (2014) found that three-split application maintained a continuous supply of nutrients, which might have favored the crop for higher values of yield attributes [50]. In our study, T1 decreased yield compared with T2 under N3 in 3 years. The decrease in grain yield may be due to the fact that excessive basal $\mathrm{N}$ application might have led to an insufficient supply of dry matter for the reproductive stage and delayed plant maturity, as it favored continued vegetative growth [51]. The grain yield varied between 2649 and $8543 \mathrm{~kg} \mathrm{ha}^{-1}$ in 2018, 4156 and $11,858 \mathrm{~kg} \mathrm{ha}^{-1}$ in 2019, and 4032 and $11,854 \mathrm{~kg} \mathrm{ha}^{-1}$ in 2020. The difference in grain yield between 2018, 2019, and 2020 may result from the fact that rain-fed agriculture is more easily affected by variation in precipitation and N stimulation [52]. Grain yield was impacted by physiological processes at different growing stages, especially the jointing stage [30]. Appropriate $\mathrm{N}$ fertilization could increase antioxidant enzymes, chlorophyll content, and LAI, improving plant photosynthetic efficiency. As a result, this promoted the accumulation of dry matter and increased grain yield [52,53]. In our study, correlation analysis showed that antioxidant enzymes, morphology, and photosynthetic capacity at jointing was positively correlated with yield under different $\mathrm{N}$ supplies. It provides evidence for increasing yield by improving morphological and physiological processes.

\section{Conclusions}

The results of a 3-year field study showed that both 200 and $300 \mathrm{~kg} \cdot \mathrm{N} \cdot \mathrm{ha}^{-1}$ fertilization could optimize antioxidant enzyme systems, increasing photosynthetic capacity, and then, promoting dry matter accumulation, thus benefiting maize yield. However, there was no significant difference between grain yield of 200 and $300 \mathrm{~kg} \mathrm{~N} \mathrm{ha}^{-1}$, and $\mathrm{N}$ timing had a very weak effect on yield and the physiological indicators mentioned above. Thus, fertilization of $200 \mathrm{~kg} \mathrm{~N} \cdot \mathrm{ha}^{-1}$ is optimal for rainfed maize in the Loess Plateau of China. Further studies should be done on more cultivars and crop seasons to deepen insight into the physiological response of maize to $\mathrm{N}$ fertilization. In addition, more $\mathrm{N}$ ratios (between 200 and $300 \mathrm{~kg} \mathrm{~N} \mathrm{ha}^{-1}$ ) at two different times should be taken into consideration in order to obtain the best $\mathrm{N}$ management practice to increase yield.

Author Contributions: Conceptualization, K.Y. and L.L.; methodology, K.Y. and J.X.; software, S.K.F.; validation, K.Y., L.L. and R.Z.; formal analysis, Z.L.; investigation, K.Y.; resources, J.X.; data curation, K.Y.; writing—original draft preparation, K.Y.; writing—review and editing, K.Y., L.L., S.K.F. and S.A. All authors have read and agreed to the published version of the manuscript.

Funding: This research was supported by the National Natural Science Foundation of China (31761143004 and 31660373), the Education Department of Gansu Province (2017C-12), and the Department of Science and Technology of Gansu Province (GSPT-2018-56).

Acknowledgments: We appreciate assistance in the field and laboratory by students of the Rainfed Agricultural Experimental Station of Gansu Agricultural University.

Conflicts of Interest: The authors declare no conflict of interest. 


\section{References}

1. Ciampitti, I.A.; Vyn, T.J. Physiological Perspectives of Changes over Time in Maize Yield Dependency on Nitrogen Uptake and Associated Nitrogen Efficiencies: A Review. Field Crops Res. 2012, 133, 48-67. [CrossRef]

2. Tilman, D.; Balzer, C.; Hill, J.; Befort, B.L. Global Food Demand and the Sustainable Intensification of Agriculture. Proc. Natl. Acad. Sci. USA 2011, 108, 20260-20264. [CrossRef]

3. Zheng, J.; Fan, J.L.; Zhang, F.C.; Yan, S.C.; Xiang, Y.Z. Rainfall Partitioning into Throughfall, Stemflow and Interception Loss by Maize Canopy on the Semi-Arid Loess Plateau of China. Agric. Water Manag. 2018, 195, 25-36. [CrossRef]

4. Zhang, X.D.; Cai, H.J.; Fu, Y.J.; Wang, J. Study on Leaf Area Index of Summer Maize in Loess Areas. Agric. Res. Arid Areas. 2005, $24,25-29$.

5. Ju, X.T.; Xing, G.X.; Chen, X.P.; Zhang, S.L.; Zhang, L.J.; Liu, X.J.; Cui, Z.L.; Yin, B.; Christie, P.; Zhu, Z.L.; et al. Reducing Environmental Risk by Improving N Management in Intensive Chinese Agricultural Systems. Proc. Natl. Acad. Sci. USA 2009, 106, 3041-3046. [CrossRef]

6. Morell, F.J.; Lampurlanés, J.; Álvaro-Fuentes, J.; Cantero-Martínez, C. Yield and Water Use Efficiency of Barley in a Semiarid Mediterranean Agroecosystem: Long-Term Effects of Tillage and N Fertilization. Soil Till. Res. 2011, 117, 76-84. [CrossRef]

7. Sharifi, R.S.; Namvar, A. Effects of Time and Rate of Nitrogen Application on Phenology and Some Agronomical Traits of Maize (Zea Mays L.). Biologija 2016, 62, 35-45. [CrossRef]

8. Fernandez, J.A.; DeBruin, J.; Messina, C.D.; Ciampitti, I.A. Late-Season Nitrogen Fertilization on Maize Yield: A Meta-Analysis. Field Crops Res. 2020, 247, 107586. [CrossRef]

9. Li, H.; Kuang, N.; Gou, Q.; Ma, Y.; Li, Q. Effects of Different Film Mulches on Photosynthetic Characteristics and Yield of Summer Maize (Zea Mays L.) in the North China Plain. Arch. Agron. Soil Sci. 2021, 67, 179-190. [CrossRef]

10. Hallof, N.; Sárvári, M. Effect of Different Fertilizer Doses on Yield, LAI and Photosynthetic Activity of Maize Hybrids. Cereal Res. Commun. 2006, 34, 441-444. [CrossRef]

11. Denis, B.; Marcelo, M.; Lucia, M. Nitrogen Supply Influences Photosynthesis Establishment along the Sugarcane Leaf. Sci. Rep. 2018, 8, 2327.

12. Uribelarrea, M.; Crafts-Brandner, S.J.; Below, F.E. Physiological N Response of Field-Grown Maize Hybrids (Zea Mays L.) with Divergent Yield Potential and Grain Protein Concentration. Plant. Soil 2009, 316, 151. [CrossRef]

13. Li, D.; Tian, M.; Cai, J.; Jiang, D.; Cao, W.; Dai, T. Effects of Low Nitrogen Supply on Relationships Between Photosynthesis and Nitrogen Status at Different Leaf Position in Wheat Seedlings. Plant. Growth Regul. 2013, 70, 257-263. [CrossRef]

14. Zhang, Z.; Zhang, Y.; Shi, Y.; Yu, Z. Optimized Split Nitrogen Fertilizer Increase Photosynthesis, Grain Yield, Nitrogen Use Efficiency and Water Use Efficiency under Water-Saving Irrigation. Sci. Rep. 2020, 10, 1-14. [CrossRef]

15. Stevens, W.B.; Hoeft, R.G.; Mulvaney, R.L. Fate of $15 \mathrm{~N}$ in a Long-Term Nitrogen Rate Study: I. Interactions with Soil Nitrogen. Agron. J. 2005, 97, 1037-1045. [CrossRef]

16. Okamura, M.; Arai-Sanoh, Y.; Yoshida, H.; Mukouyama, T.; Adachi, S.; Yabe, S.; Nakagawa, H.; Tsutsumi, K.; Taniguchi, Y.; Kobayashi, N.; et al. Characterization of High-Yielding Rice Cultivars with Different Grain-Filling Properties to Clarity Limiting Factors for Improving Grain Yield. Field Crops Res. 2018, 219, 139-147. [CrossRef]

17. Kochhar, S.; Kochhar, V.K. Expression of Antioxidant Enzymes and Heat Shock Proteins in Relation to Combined Stress of Cadmium and Heat in Vigna Mungo Seedlings. Plant. Sci. 2005, 168, 921-929. [CrossRef]

18. Ahmadi, A.; Emam, Y.; Pessarakli, M. Biochemical Changes in Maize Seedlings Exposed to Drought Stress Conditions at Different Nitrogen Levels. J. Plant. Nutr. 2010, 33, 541-556. [CrossRef]

19. Wu, J.; Fu, T.; Zheng, C.; Yang, G.; Shen, F. Effects of Nitrogen Fertilizer on Biomass, Chlorophyll Content and Antioxidant Enzyme Activities of Picris Japonica Thunb under Pb Stress. Acta Agric. Boreali Sin. 2015, 30, 213-218.

20. Zhang, Z.; Yu, Z.; Zhang, Y.; Shi, Y. Split Nitrogen Fertilizer Application Improved Grain Yield in Winter Wheat (Triticum Aestivum L.) Via Modulating Antioxidant Capacity and $13 \mathrm{C}$ Photosynthate Mobilization under Water-Saving Irrigation Conditions. Ecol. Process. 2021, 10, 1-13. [CrossRef]

21. Zhao, Q.; Zhou, L.; Liu, J.; Du, X.; Huang, F.; Pan, G.; Cheng, F. Relationship of ROS Accumulation and Superoxide Dismutase Isozymes in Developing Anther with Floret Fertility of Rice under Heat Stress. Plant Physiol. Biochem. 2018, 122, 90-101. [CrossRef]

22. Shah, K.; Nahakpam, S. Heat Exposure Alters the Expression of SOD, POD, APX and CAT Isozymes and Mitigates Low Cadmium Toxicity in Seedlings of Sensitive and Tolerant Rice Cultivars. Plant. Physiol. Biochem. 2012, 57, 106-113. [CrossRef]

23. Walsh, O.; Raun, W.; Klatt, A.; Solie, J. Effect of Delayed Nitrogen Fertilization on Maize (Zea Mays L.) Grain Yields and Nitrogen Use Efficiency. J. Plant. Nutr. 2012, 35, 538-555. [CrossRef]

24. FAO. Soil Map of the World: Revised Legend. In World Soil Resources Report; FAO: Rome, Italy, $1990 ;$ Volume 60.

25. Xie, J.; Chai, Q.; Li, L.; Zhang, R.; Niu, Y.; Luo, Z. The Time Loading Limitation of Continuous Cropping Maize Yield under Different Plastic Film Mulching Modes in Semi-Arid Region of Loess Plateau of China. Sci. Agric. Sin. 2015, 48, 1558-1568.

26. Wei, S.; Wang, X.; Shi, D.; Li, Y.; Zhang, J.; Liu, P.; Zhao, B.; Dong, S. The Mechanisms of Low Nitrogen Induced Weakened Photosynthesis in Summer Maize (Zea Mays L.) under Field Conditions. Plant. Physiol. Biochem. 2016, 105, 118-128. [CrossRef]

27. Wang, P.; Zhang, X.L.; Shi, L. Changes of Photosynthetic Characteristics and Chlorophyll Fluorescence Parameters of Pugionium Cornutum (L.) Gaertn Seedlings Leaf under Drought Stress. Agric. Res. Arid Areas 2017, 35, 159-163.

28. Li, H. Principles and Techniques of Plant Physiological Biochemical Experiment; Higher Education Press: Beijing, China, 2000.

29. He, Z.X.; Zhang, S.Z. Electrophoresis. The Second Press; Science Press: Beijing, China, 1999. 
30. Liu, H.; Huang, X.; Huang, M.; Chi, B.; Zheng, X.; Chen, J. Effects of Drought Stress at Jointing Stage on Yield and Drought Resistance in Spring Maize. Crops 2016, 2, 89-94.

31. Cai, H.G.; Yuan, J.C.; Liu, J.Z.; Yan, G.X.; Zhang, H.X.; Liang, Y. Optimal Nitrogen Application Rate and Nitrogen Requirement Characteristics in Spring Maize under High Planting Density Condition. Sci. Agric. Sin. 2017, 50, $1995-2005$.

32. Jin, X.; Li, W.; Hu, D.; Shi, X.; Zhang, X.; Zhang, F.; Fu, Z.; Ding, D.; Liu, Z.; Tang, J. Biological Responses and Proteomic Changes in Maize Seedlings under Nitrogen Deficiency. Plant. Mol. Biol. Rep. 2015, 33, 490-504. [CrossRef]

33. Wasaya, A.; Tahir, M.; Ali, H.; Hussain, M.; Yasir, T.A.; Sher, A.; Ijaz, M. Influence of Varying Tillage Systems and Nitrogen Application on Crop Allometry, Chlorophyll Contents, Biomass Production and Net Returns of Maize (Zea mays L.). Soil Tillage Res. 2017, 170, 18-26. [CrossRef]

34. Millard, P. The Accumulation and Storage of Nitrogen by Herbaceous Plants. Plant. Cell Environ. 1998, 11, 1-8. [CrossRef]

35. Zhou, B.; Sun, X.; Ding, Z.; Ma, W.; Zhao, M. Multisplit Nitrogen Application Via Drip Irrigation Improves Maize Grain Yield and Nitrogen Use Efficiency. Crop. Sci. 2017, 57, 1687-1703. [CrossRef]

36. Cheng, Z.; Ya, F.U.; Zong, S. Relationship between Leaf Senescence and Activated Oxygen Metabolism in Super High Yielding Rice During Flowering and Grain Formation Stage. Chin. J. Rice Sci. 2002, 16, 326-330.

37. Mu, X.; Chen, Q.; Chen, F.; Yuan, L.; Mi, G. A RNA-seq Analysis of the Response of Photosynthetic System to Low Nitrogen Supply in Maize Leaf. Int. J. Mol. Sci. 2017, 18, 2624. [CrossRef]

38. Vos, J.; Van Der Putten, P.E.L.; Birch, C.J. Effect of Nitrogen Supply on Leaf Appearance, Leaf Growth, Leaf Nitrogen Economy and Photosynthetic Capacity in Maize (Zea mays L.). Field Crops Res. 2005, 93, 64-73. [CrossRef]

39. Liu, J.Z.; Yuan, J.C.; Zhou, K.; Liang, Y.; Yan, X.G.; Zhang, H.X.; Ren, J.; Cai, H.J. Effect of Different Nitrogen Fertilizer Application Rates on Photosynthetic Characteristic and Yield. J. Maize Sci. 2019, 27, 151-157.

40. Farquhar, G.D.; Sharkey, T.D. Stomatal Conductance and Photosynthesis. Ann. Rev. Plant. Physiol. 1982, 33, 317-345. [CrossRef]

41. Ma, X.; Zheng, J.; Zhang, X.; Hu, Q.; Qian, R. Salicylic Acid Alleviates the Adverse Effects of Salt Stress on Dianthus superbus by Activating Photosynthesis, Protecting Morphological Structure, and Enhancing the Antioxidant System. Front. Plant. Sci. 2017, 8, 600. [CrossRef]

42. Li, C. Effects of Enhanced Ammonium Nutrition on Growth and Development of Maize. J. Northeast. Agric. Univ. 2002, 33, 313-318.

43. Wang, J.Z.; Zhang, C.N.; Zhao, H.J. Effects of Different Fertilization Methods on Chlorophyll Fluorescence Parameters and Yield of Summer Maize. Plant. Nutr. Fert. Sci. 2008, 14, 479-483.

44. Zakari, S.A.; Asad, M.A.U.; Han, Z.; Zhao, Q.; Cheng, F. Relationship of Nitrogen Deficiency-Induced Leaf Senescence with ROS Generation and ABA Concentration in Rice Flag Leaves. J. Plant. Growth Regul. 2020, 1-15. [CrossRef]

45. Shin, R.; Berg, R.H.; Schachtman, D.P. Reactive Oxygen Species and Root Hairs in Arabidopsis Root Response to Nitrogen, Phosphorus and Potassium Deficiency. Plant. Cell Physiol. 2005, 46, 1350-1357. [CrossRef]

46. Wang, H.Z.; Zhang, J.; Wu, J.Z.; Xu, G.W.; Chen, M.C.; Fu, G.Z.; Li, Y.J. Effect of Different Levels of Nitrogen on Physiological Characteristics of Flag Leaves and Grain Yield of Wheat. Acta Prataculturae Sin. 2013, 22, 69-75.

47. Solórzano, E.; Corpas, F.J.; González-Gordo, S.; Palma, J.M. Reactive Oxygen Species (Ros) Metabolism and Nitric Oxide (No) Content in Roots and Shoots of Rice (Oryza Sativa L.) Plants under Arsenic-Induced Stress. Agronomy 2020, 10, 1014. [CrossRef]

48. Song, Y.; Li, J.; Liu, M.; Meng, Z.; Liu, K.; Sui, N. Nitrogen Increases Drought Tolerance in Maize Seedlings. Funct. Plant. Biol. 2019, 46, 350-359. [CrossRef]

49. Chen, Y.; Xiao, C.; Wu, D.; Xia, T.; Chen, Q.; Chen, F.; Yuan, L.; Mi, G. Effects of Nitrogen Application Rate on Grain Yield and Grain Nitrogen Concentration in Two Maize Hybrids with Contrasting Nitrogen Remobilization Efficiency. Eur. J. Agron. 2015, 62, 79-89. [CrossRef]

50. Joshi, A.; Gupta, J.K.; Choudhary, S.K.; Paliwal, D.K. Efficiency of Different Nitrogen Source, Doses and Split Application on Growth and Yield of Maize (Zea Mays L.) in the Malwa Region of Madhya Pradesh. IOSR J. Agric. Veter. Sci. 2014, 7, $2319-2372$. [CrossRef]

51. Zhang, L.; Liu, H.H.; Sun, J.Q.; Li, J.C.; Song, Y.H. Seeding Characteristics and Grain Yield of Maize Grown Under Straw Retention Affected by Sowing Irrigation and Splitting Nitrogen Use. Field Crops Res. 2018, 225, 22-31. [CrossRef]

52. Lamptey, S.; Li, L.; Xie, J.; Zhang, R.; Yeboah, S.; Antille, D.L. Photosynthetic Response of Maize to Nitrogen Fertilization in the Semiarid Western Loess Plateau of China. Crop. Sci. 2017, 57, 2739-2752. [CrossRef]

53. Acciaresi, H.A.; Tambussi, E.A.; Antonietta, M.; Zuluaga, M.S.; Andrade, F.H.; Guiamét, J.J. Carbon Assimilation, Leaf Area Dynamics, and Grain Yield in Contemporary Earlier-and Later-Senescing Maize Hybrids. Eur. J. Agron. 2014, 59, 29-38. [CrossRef] 